\title{
Periodic Table of the Elements, History, Education and Evaluation
}

Tabla periódica de los elementos, historia, educación y evaluación

Fecha de recepción y aceptación: 17 de febrero de 2021 y 22 de abril de 2021

DOI: $10.46583 /$ nereis_2021.13.808

\section{Francisco Torrens Zaragozá ${ }^{*}$}

${ }^{1}$ Institut Universitari de Ciència Molecular. Universitat de València.

* Correspondencia: Universitat de València. Institut Universitari de Ciència Molecular. Edifici d'Instituts de Paterna. P. O. Box 22085. 46071 València. Spain.E-mail: torrens@uv.es. ORCID: 0000-0002-8534-208X

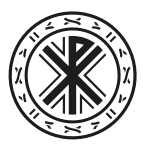

Universidad Católica de Valencia San Vicente Mártir

\section{ABSTRACT}

The periodic tables of transition metal thiophosphates $M \mathrm{PS}_{3}$, transition metal dichalcogenides $\mathrm{MX}_{2}$ and other materials, the origin of chemical elements and toxic trace elements in dried mushrooms are provided. The effective nucleus-electron attraction is proportional to the effective nuclear charge $\left(Z_{\text {eff }}\right)$ and inversely proportional to the effective principal quantum number $\left(n^{*}\right)$. The periodic arch is one of many modern visual displays that have been developed to augment the traditional periodic table of the chemical elements. The table is related to the multiparameter optimisation of $\mathrm{N}$ atom, nuclear magnetic resonance and everyday life. Educational activities were developed and evaluated.

KEYWORDS: Atomic radius, Gordy atomic electronegativity scale, Ionisation energy, Mulliken electronegativity.

\section{RESUMEN}

Se proporcionan las tablas periódicas de los tiofosfatos de metales de transición $M \mathrm{PS}_{3}$, los dicalcogenuros de metales de transición $\mathrm{MX}_{2} \mathrm{y}$ otros materiales, el origen de los elementos químicos y elementos traza tóxicos en setas secas. La atracción efectiva núcleo-electrón es proporcional a la carga nuclear efectiva $\left(Z_{\text {eff }}\right)$ e inversamente proporcional al número cuántico principal efectivo $\left(n^{*}\right)$. El arco periódico es una de las muchas presentaciones visuales modernas que se han desarrollado para aumentar la tabla periódica tradicional de los elementos químicos. La tabla se relaciona con la optimización multiparamétrica del átomo de $\mathrm{N}$, la resonancia magnética nuclear y la vida cotidiana. Se desarrollan actividades educativas con evaluación.

PALABRAS CLAVE: Radio atómico, escala de electronegatividad atómica de Gordy, energía de ionización, electronegatividad de Mulliken. 


\section{INTRODUCTION}

Setting the scene: the periodic table of the elements (PTE) of transition metal thiophosphates $M_{\mathrm{PS}}$ $(M=\mathrm{Mn}-\mathrm{Ni}, \mathrm{Zn})$, PTE of transition metal dichalcogenides (TMDCs) $\mathrm{MX}_{2}$ and other materials, the orbital exponent efficacy to study the periodic parameters (PPs), periodic arch (PA), the origin of chemical elements, PTE of toxic trace elements in dried mushrooms, PTE and its relationship with the multiparameter optimisation of $\mathrm{N}$ atom, PTE and its relationship with nuclear magnetic resonance (NMR), PTE and its relationship to everyday life, PTE with drawings about the daily use of each of them, PTE showing the actual utility of each chemical element, the elements of PTE in articles of daily life, the best illustrated PTE, etc. What are atoms? Atom (uncuttable). How big is an atom? The PTE displays all known chemical elements grouped by their chemical properties and atomic structure. How are the elements grouped? Sets of elements are metals, metalloids and non-metals, groups, periods, categories and blocks. Copper $/ \mathrm{Ag} / \mathrm{Au} / \mathrm{Hg} / \mathrm{Sn} / \mathrm{Pb}$, etc. were known since ancient times and were used to make jewellery, coins and tools. Phosphorus became the first element to be discovered by Hennig Brand (1649). It is known as the first scientific discovery of a chemical element. The PTE arranges the chemical elements, e.g., $\mathrm{H} / \mathrm{Si} / \mathrm{Fe} / \mathrm{U}$, according to their recurring properties. The number of each element [atomic number $(Z=$ No. protons)] corresponds to the number of protons in its nucleus. The PTE is a product of the collective creativity of $19^{\text {th }}$-century science classrooms. The celebration during 2019 of the International Year of PTE should have served, among other things, to recall that the publication of the first version of the Russian Dmitri Mendeleev's PTE (1869) was conditioned by the fact that he had to complete his chemistry textbook for his first-year students at St. Petersburg University. Bertomeu Sánchez and Muñoz Bello reviewed inorganic Darwinism, chemical pedagogy and popularisation of science in the periodic law (PL) in Spain at the end of the $19^{\text {th }}$ century [1]. What is the world made of? How advances in scientific research change working hypotheses? How is the PTE organised and arranged? In 1913, much of basic science remained unresolved. How old is the Earth? What does an atom look like? Are there planets beyond Neptune? Where does the Sun's energy come from? Are there elements lighter than H? Why, fundamentally, is one element different from another? Teaching physics and chemistry via its history. For many people, the PTE is a blurry memory of high school stuffed in a box at the bottom of the brain; they are unable to remember the chemical elements or their importance. However, what if people were told where everyone is in everyday life? A father has drawn the PTE with the 118 elements and their applications in daily life. The American physicist creates a website to facilitate the teaching of chemistry to children. Although it is easy to identify things made with $\mathrm{Ag} / \mathrm{Cu} / \mathrm{Na}$, people have no idea that some elements, e.g. W/Dy, are closer than they think. With a PTE, students learn chemistry via objects that they use in their daily lives. How far does the PTE go? Efforts to fill the PTE raise questions (Qs) of special relativity that strike at the heart of chemistry as a discipline. Is it time to upend the PTE? How did the PTE get its name? How did the PTE get its shape? Does each new PTE supersede all the previous ones? Earlier publications reported reflections on the nature of the PTE and its implications in chemistry education [2], nanoscience from a two-dimensional (2D) to a three-dimensional (3D) PTE [3], PTE; the quantum biting its tail, sustainable chemistry [4], Periodic Law (PL) [5], periodic properties (electron configuration, atomic radii, ionisation energy, electronegativity, electron affinity, metallic character) [6], PTE [7], the PTE; heavy, rare, critical and super elements [8], the PTE; the nature of the chemical 
bond, nonclassical compounds [9], mesoporous graphene composite, the Li battery, topology, periodicity [10], surfaces, quantum walks, knowledge, agrotoxins and the PTE [11]. This article reviews the PTE of transition metal thiophosphates $M \mathrm{PS}_{3}$, PTE of TMDCs $\mathrm{MX}_{2}$ and other materials, the orbital exponent efficacy to study the PPs, the Periodic Arch (PA) and the origin of chemical elements, PTE of toxic trace elements in dried mushrooms, PTE and its relationship with the multiparameter optimisation of N atom, PTE and its relationship with NMR, the PTE and its relationship with everyday life, PTE with drawings about the daily use of each of them, the PTE showing the actual utility of each chemical element, the elements of the PTE in articles of daily life, the best illustrated PTE to study the elements and find out, the PTE in everyday objects, the PTE showing one where each chemical element is in everyday life, from the cell phone to a submarine; why people use each chemical element in daily life, everyday objects to explain the chemical elements, a ten-question quiz on the PTE, the development of an educational activity, chemical elements, society and the Project: The Elements of the PTE in Daily Life. The aim of this work is to initiate a debate by suggesting a number of questions that can arise when addressing subjects of how things are in the universe now, etc. Possible answers (As) and hypotheses are provided.

\section{PERIODIC TABLE OF THE ELEMENTS OF TRANSITION METAL THIOPHOSPHATES MPS ${ }_{3}$}

Figure 1 shows the PTE of transition metal thiophosphates $M_{\mathrm{PS}}[M=\mathrm{Mn}-\mathrm{Ni}, \mathrm{Zn}$, oxidation states (OS) 2, 3], a class of van der Waals stacked insulating antiferromagnets, which could be exfoliated down to the ultrathin limit [12].

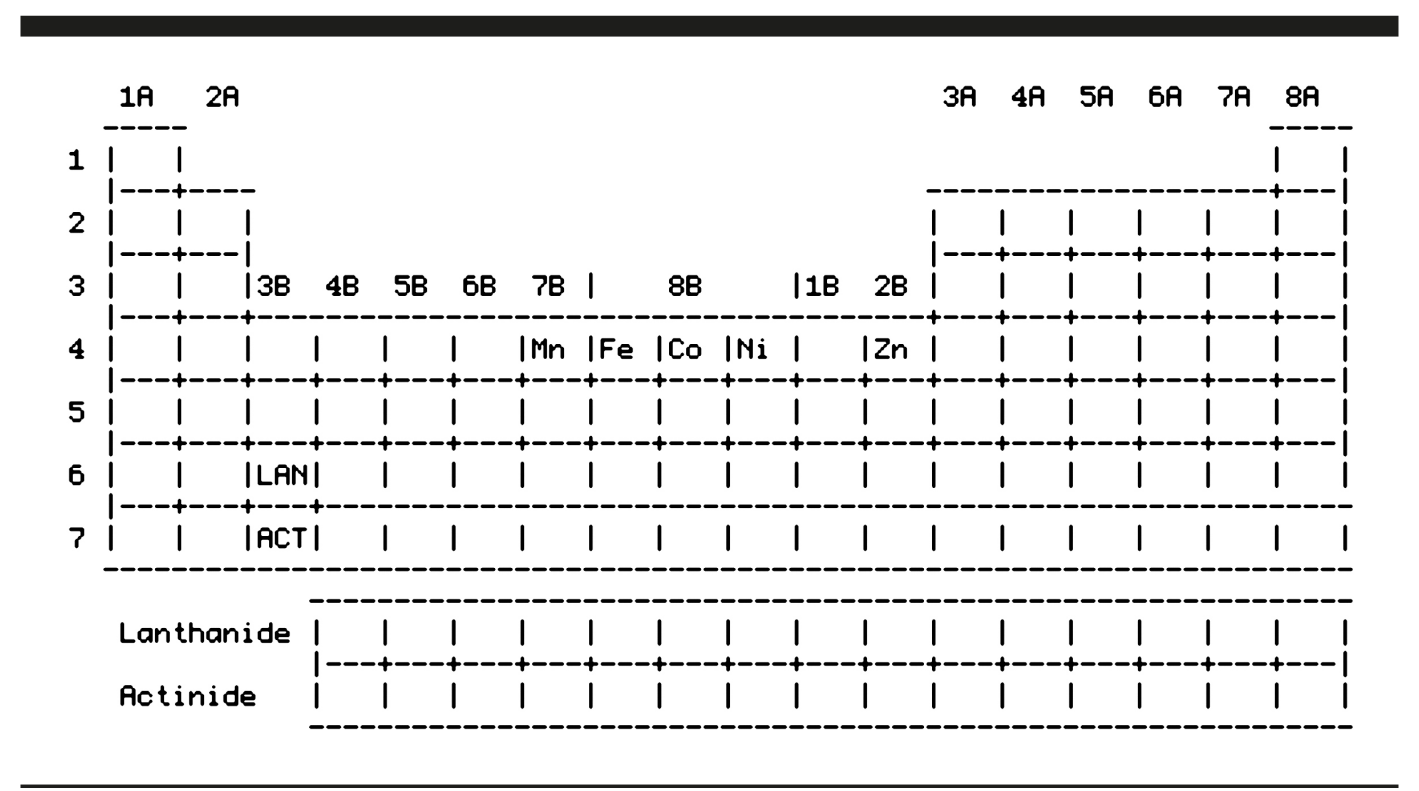

Fig. 1. The periodic table of the elements of van der Waals materials $M \mathrm{PS}_{3}(M=\mathrm{Mn}-\mathrm{Ni}, \mathrm{Zn})$. Source: own elaboration. 


\section{PTE OF TRANSITION METAL DICHALCOGENIDES MX 2 AND OTHER MATERIALS}

Figure 2 shows the PTE of TMDCs $\mathrm{MX}_{2}[M=\mathrm{Ti}, \mathrm{V}, \mathrm{Co}, \mathrm{Ni}, \mathrm{Zr}-\mathrm{Tc}, \mathrm{Rh}, \mathrm{Pd}, \mathrm{Hf}-\mathrm{Re}, \mathrm{Ir}, \mathrm{Pt} ; \mathrm{X}=\mathrm{S}$, Se, Te; OS 4, 2, 5, 6, 7] [13].

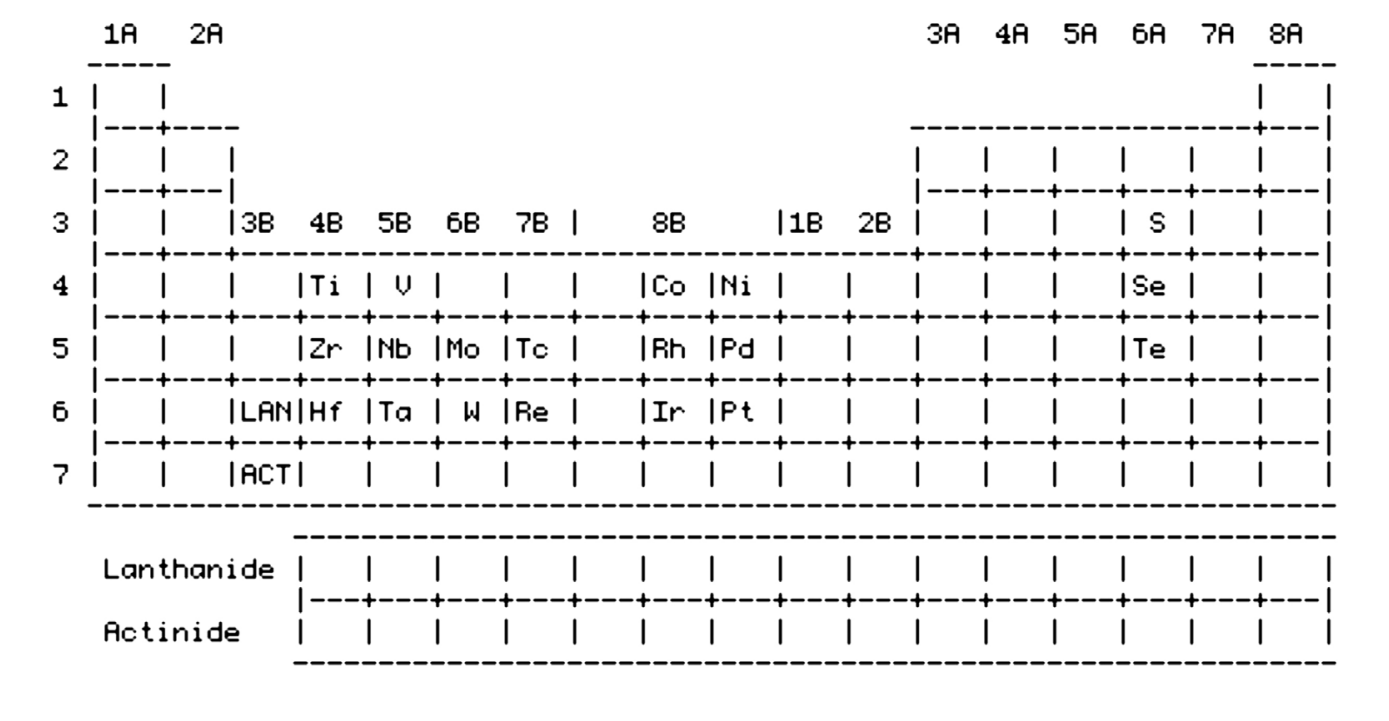

Fig. 2. The periodic table of the elements of transition metal dichalcogenides $\mathrm{MX}_{2}$ and other materials. Source: own elaboration.

\section{THE ORBITAL EXPONENT EFFICACY TO STUDY THE PERIODIC PARAMETERS}

Reed's suggestions for the evaluation of screening constants of $s / p / d$-block elements were considered and Reed's rule for the evaluation of screening constants of $f$-block elements was extended [14]. When electron entire in 5f/6p and higher, the contribution of $4 \mathrm{f}$ as 1 was used. In the same shell, $\mathrm{f}$ electrons shield each other by a factor of 0.3228 .

\section{PERIODIC ARCH}

The PA represents the kind of mindset that is usually shared by engineers and artists [15]. Electromagnetic signals are the root issue that needs to be revisited. Until the review is fully accomplished and widely disseminated, nanotechnology and other technologically important areas will be unnecessarily hampered. 


\section{THE ORIGIN OF CHEMICAL ELEMENTS}

Cortina proposed the following questions and answers on the origin of chemical elements [16].

Q1. How are things in the universe now?

A1. The world according to astronomers (figure 3): H (71.6 \%, green); He (27\%, red); metals $(2 \%$, black $)$.

Q2. Where is He produced after the Big Bang (BB)?

Q3. In addition, where are the metals produced?

Q4. Where can people find the answer?

A4. Astrophysics and nuclear physics.

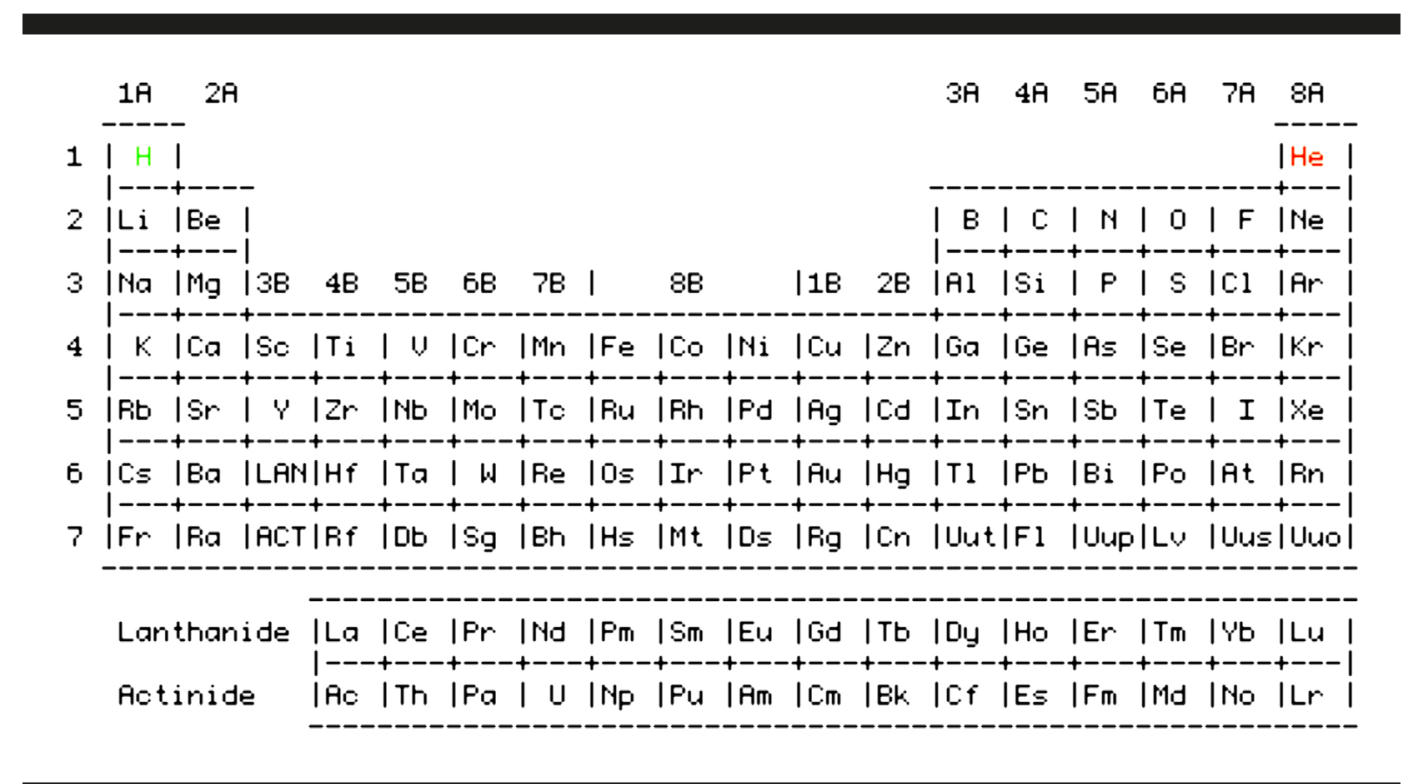

Fig. 3. The PTE of the origin of chemical elements. The world according to astronomers: H (green); He (red); metals (black). Source: own elaboration. 


\section{THE PERIODIC TABLE OF TOXIC TRACE ELEMENTS IN DRIED MUSHROOMS}

Figure 4 shows the PTE of toxic trace elements in dried mushrooms [As, $\mathrm{Cd}, \mathrm{Hg}, \mathrm{Pb}$; OS 2, 1, 3, $4,5,-3][17-19]$.

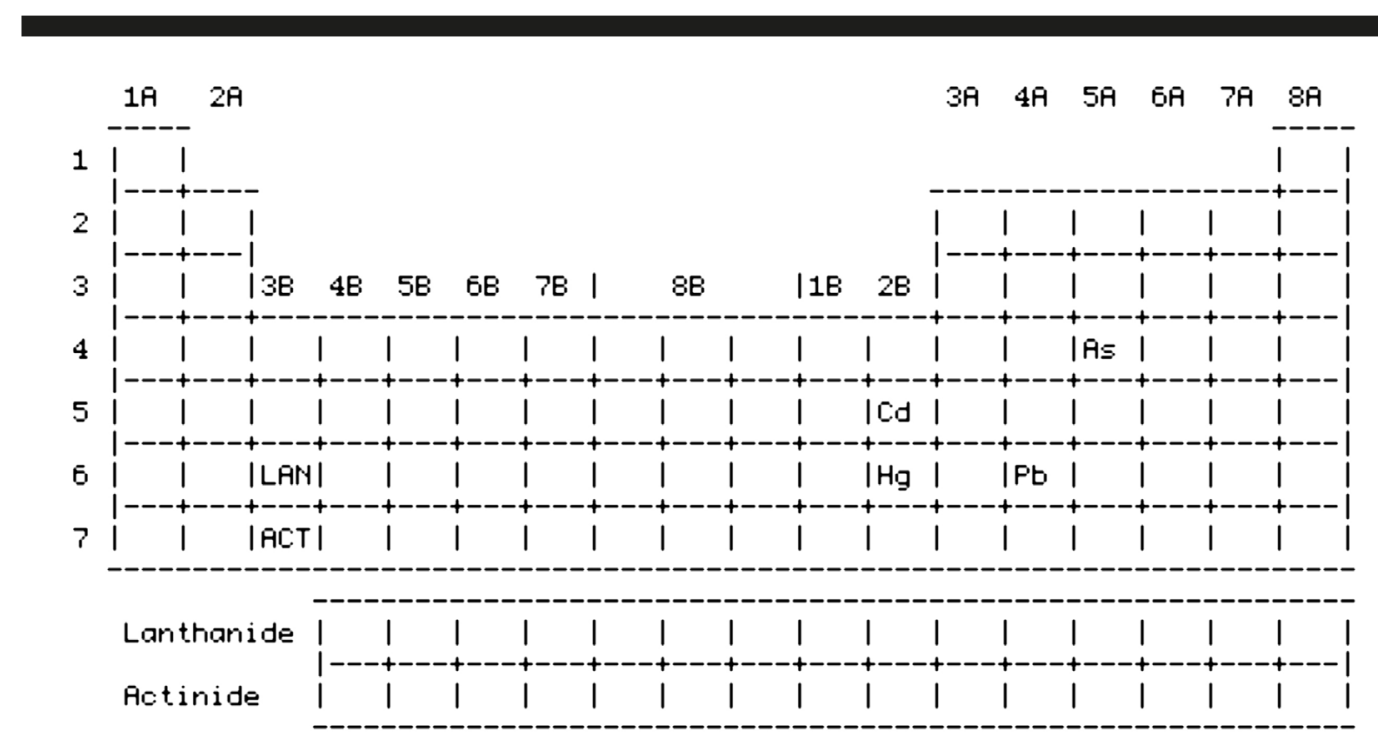

Fig. 4. The periodic table of toxic trace elements in dried mushrooms. Source: own elaboration.

\section{RELATIONSHIP OF THE PTE WITH MULTIPARAMETER OPTIMISATION OF THE N ATOM}

Aromatic $\mathrm{CH}$ group $\rightarrow \mathrm{N}$ atom exchange is a versatile design element for multiparameter optimisation that could lead to the identification of necessary $N$ atoms. Although generic effects and general trends exist, the specific impact is always context (ligand, target, antitargets, etc.)-dependent. However, 2-aza-analogues seem to have a higher probability of positive or neutral impact across multiple pharmacological parameters (not just potency).

\section{THE PERIODIC TABLE AND ITS RELATIONSHIP WITH NUCLEAR MAGNETIC RESONANCE}

The following questions were raised on the PTE and its relationship with NMR.

Q1. How do atomic properties manifest in NMR spectra, via, e.g., F?

Q2. How to use selective ${ }^{19} \mathrm{~F},{ }^{13} \mathrm{C}$ and ${ }^{2} \mathrm{H}$-labelling to map structural features? 


\section{THE PERIODIC TABLE OF THE ELEMENTS AND ITS RELATIONSHIP WITH EVERYDAY LIFE}

In this group, a study dealt with the relationship of the PTE with food and the way this interacts with the human body [20]. In the cases of elements without application in the food area, whether the element possesses radioactivity and its application in other fields was indicated. The main purpose of the research was to make the chemistry studies more attractive and approachable to the students of science, establishing practical relations between the PTE and the chemical components of people's daily life.

\section{TABLE OF THE ELEMENTS, WITH DRAWINGS ABOUT THE DAILY USE OF EACH OF THEM}

The PTE with drawings by Keith Enevoldsen shows with words and everyday objects what each of the known chemical elements is used for [21]: from Li (batteries) to He (balloons) or Xe (high-intensity lamps). The original image is gigantic and it is better to consult it on the original page; however, the content is extremely easy to understand and selfexplanatory. Each element includes the atomic symbol, Z, its name in English, a symbol that indicates if it is solid/liquid/gas $(\mathrm{S} / \mathrm{L} / \mathrm{G})$ at room temperature, and others that show if it is found in the human body, if it is magnetic, radioactive, etc. It is something that deserves to be admired and even printed in poster size to hang in class or the office.

\section{THE PERIODIC TABLE SHOWING THE ACTUAL UTILITY OF EACH CHEMICAL ELEMENT}

Chemistry is one of the subjects considered as a bore in the life of every student [22]. Memorizing the elements of the PTE during secondary school (e.g., valences, atomic mass, Z) requires an effort that has cost more than one fail, because students did not understand what all those rows and columns were for. If you don't believe this, try the test. What are $\mathrm{Mn} / \mathrm{Zr} / \mathrm{Rb}$ for? An American physicist, Enevoldsen, decided to revolutionise classical chemistry and create an interactive PTE. He showed the applications that each element has in real life: from $\mathrm{H}$ to Lw. In it, Ta is shown as one of the essential elements for making mobile phones, $\mathrm{Zn}$ is used to create wind instruments, e.g., trumpets, and $\mathrm{V}$, in the manufacture of springs. According to British Broadcasting Corporation (BBC) World, his idea was always to create the PTE that he would have liked to have as a child. "I was born in 1956. When I was a child I liked PTEs with figures, but there were never good images of all the elements," he says. "I also read a book by Isaac Asimov that had wonderful stories about the history and uses of the elements. I liked finding out, e.g., that chemists who touched Te ended up with bad breath," he adds. Recalling his time as a student, he got down to work and created an interactive website in which all you have to do is to pass the mouse over the elements to find out the most common applications. It incorporates links that redirect to Google searches related to the application of each element. He trusts that his contribution will help children approach the subject in a different way. "I hope that, thanks to the PTE, children will want to know the elements as when they meet a new friend." 


\section{THE ELEMENTS OF THE PERIODIC TABLE IN ARTICLES OF DAILY LIFE}

The PTE is one of the teachings that will always have a place in people's memory of those days when they attended school [23]. Periods, groups, properties, $Z$ or the famous symbol are the things that people remember from the navigation chart of the world of chemical elements. However, just as many people find it easy to remember the symbols of the most well-known elements, others do not even remember the $\mathrm{H}$ symbol or they have little interest in it. However, in people's daily lives they are not aware that the things around them are made of elements that they had never heard of before [e.g., Dy (compact discs), Er (protective glasses)].

\section{THE BEST ILLUSTRATED PERIODIC TABLE TO STUDY THE ELEMENTS AND FIND OUT}

When Mendeleev published his PTE, he ordered the chemical elements according to the characteristics of their atoms [24]. His work opened the door to delve into the world of the constituent matter of absolutely everything that surrounds people. People have all spent hours at school and home memorising the strange names of the elements, although few really know what each of them does. That is why the interactive and illustrated PTE that Enevoldsen created and published on his website is so much appreciated. With just one click, people can find out what applications $\mathrm{Mo} / \mathrm{Kr} / \mathrm{Tl} / \mathrm{Bi}$ have in everyday life. There are many other applications: if people click, e.g., on the Pt box, in addition to its main properties, people will find out that it is a dense noncorrosive metal, useful for making laboratory equipment, constructing spark plugs, as a catalyst or in petroleum refining (cracking). If one is interested in knowing more about $\mathrm{Zr}$, you can discover that it is a metal resistant to neutrons and used to build chemical pipes and nuclear reactors, bricks for furnaces and to make zircons, those gems used in jewellery. Does Co catch anyone's eye? It is hard, serves as a raw material for making cutting tools, turbines, magnets and ceramics and it is a constituent of vitamin B12 (cobalamin), essential for the functioning of the brain. However, many other elements exist that are essential on the menu every day and that help you know exactly what you are eating. Among them, K: present, e.g. in bananas, important for neurones in performing their functions; P: found in protein-rich foods (e.g. chicken, fish, and nuts), which plays an important role in the constitution of deoxyribonucleic (DNA) and ribonucleic (RNA) acid molecules; S: found in meat, fish, garlic, onions, etc., an essential component of cells; Fe: important in the transport of $\mathrm{O}_{2}$ and cellular respiration, contained in legumes and eggs; Ca: because of its structural function, found especially in dairy products; $\mathrm{Na}$ : generally in the form of salt, essential for maintaining fluid balance in the body. "I made the PTE for myself and my children, and put it on the Internet for others to enjoy," explains Enevoldsen on BBC World. One of his inspirations was a 1958 book by Asimov, Building Blocks of the Universe, which focuses on presenting 105 elements [25]. Only 94 elements exist in nature. The rest of them, with $Z=95-118$, were created by humans in the laboratory (synthetic elements). Many have no application. Those with $Z=91-94$ were created experimentally, but later it was discovered that, although in minute quantities, they do exist in nature. Does one want to know what the latest additions were to the select club of the elements? They are the four super heavy metals: $\mathrm{Nh} / \mathrm{Mc} / \mathrm{Ts} / \mathrm{Og}$. All have a short half-life, of just seconds, and are highly 
radioactive, which makes their study difficult. They have an ephemeral existence that scientists may try to lengthen to unravel their secrets.

\section{A PTE SHOWS WHERE EACH CHEMICAL ELEMENT IS IN EVERYDAY LIFE}

The PTE synthesizes fundamental knowledge in a single image, since it shows the more than 100 elements that make up all the matter in the universe [26]. Given that many people are unaware of the relationship of these chemicals with the everyday life that surrounds them, it is worthwhile to use curious resources, e.g., the infographic developed by Enevoldsen and elements.wlonk.com [27]. Its creation is structured like a regular PTE (with the elements arranged in squares, with their assigned number, separated by colours according to their type). The novelty is that each has a small drawing and a legend. Instead of the usual symbol for each chemical element, people come across a familiar object that contains it. The conch shell caught that day at the beach owes its composition to Ca, whereas without Rn, surgical implants would not exist. Nickel is present in coins, edible fruits are rich in $\mathrm{K}$ and $\mathrm{Li}$ is essential for the batteries of electronic gadgets (and it could even explain the Big Bang). People know the relationship between $\mathrm{He}$ and balloons, or $\mathrm{Cl}$ and swimming pools. However, unexpected and surprising connections exist: Zn is found in wind instruments (e.g., tubas, trumpets), the unknown element Sc has its place in bicycles and photocopiers owe their life to Se, while Mo is present in scissors. In the upper part of the square of each element, the symbols indicate how commonly the element is found in nature, if it is found in the human body and if it is radioactive.

\section{CELL PHONE TO SUBMARINE, WHY DO PEOPLE USE CHEMICAL ELEMENTS IN DAILY LIFE?}

How does $\mathrm{Ga} / \mathrm{Ar} / \mathrm{Ta}$ influence daily life [28]? One might think of nothing, but $G a$ is an important chemical element in light-emitting diode (LED) displays. Argon is present in the light bulbs in the home, and $\mathrm{Ta}$ is used to make the microprocessor and the camera lenses of smartphones. It may seem like torture at school to have to learn each chemical element in the PTE, but relating them to objects that people use or see every day can help understand them better, which is exactly what the engineer and designer Enevoldsen was looking for when he designed a PTE with images and words showing how chemical elements play an important role in many of the objects people use. The Enevoldsen PTE presents the information found in a traditional PTE, but with small pictograms and labels that indicate the object in which each element can be found: from laptops and lighters, to laser surgery devices and nuclear submarines. The PTE is aimed at children and middle and high school students, but many adults would also be surprised and learn a little with all the information it contains. Some will surely seem obvious (e.g. Na in salt, Ne for illuminated signs) but who knew that $\mathrm{Kr}$ exists in headlights, $S$ in eggs, $S c$ in bicycles, $S b$ in car batteries or $S r$ in the fireworks? Each element has a description and a list of its uses. The PTE is also colour-coded to show how elements are grouped, their atomic number $Z$ or if their most common state of aggregation is solid, liquid or gas (S/L/G). If the chemical element is common in the human body or in the earth's crust, this information is shown and also if it is radioactive, magnetic, noble or how easily found in nature. 


\section{EVERYDAY OBJECTS TO EXPLAIN THE CHEMICAL ELEMENTS}

Mendeleev was the creator of the first version of the popular PTE [29]. Since then, variants emerged that facilitate the knowledge and memorization of chemical compounds for students [30]. One of the most practical is the PTE proposed by Enevoldsen: a PTE based on everyday objects to explain the chemical elements [31]. What does it consist of? How do chemical elements relate to the real world? These are the questions that Enevoldsen asked himself. He decided to design a PTE that reflected the uses of each element in the everyday environment. Each chemical element is accompanied not only by its name, symbol and $Z$ but by an illustration that appears next to the data that reveals which objects contain that element. Students will associate, e.g. W with light bulbs, Na with salt, or K with fruits and vegetables. The PTE is divided into colours that correspond to the different chemical groups: alkali metals, alkaline earth metals, $\mathrm{C}, \mathrm{N}$, chalcogens, halogens and noble gases. The state of aggregation of each element $(\mathrm{S} / \mathrm{L} / \mathrm{G})$ and the usual place where it is found (earth's crust, nature, people's human body) are specified.

\section{A TEN-QUESTION QUIZ ON THE PERIODIC TABLE OF THE ELEMENTS}

A ten-question quiz on PTE follows [32].

Q1. The atomic number of an atom is the number of in the atom's nucleus:
(a) Electrons.
(b) Neutrons.
(c) Neutrinos.
(d) Valence electrons.
(e) Protons.

Q2. Elements in the same column of PTE have what in common?
(a) The same atomic weight.
(b) The same number of electrons in the outermost shell.
(c) The same total number of electrons.
(d) The same number of electron shells.
(e) The same melting and boiling points.

Q3. What are the horizontal rows of the PTE called?
(a) Bases.
(b) Shells.
(c) Layers.
(d) Periods.
(e) Strata. 
Q4. What family of elements is in the rightmost column of the PTE?
(a) Alkali metals.
(b) Transition metals.
(c) Halogens.
(d) Actinoids.
(e) Noble gases.

Q5. What family of elements is in the leftmost column of PTE?
(a) Alkali metals.
(b) Transition metals.
(c) Halogens.
(d) Actinoids.
(e) Noble gases.

Q6. Elements in the PTE are listed in order of their
(a) Atomic number.
(b) Electrons.
(c) Density.
(d) Melting point.
(e) They are listed in alphabetical order.

Q7. Which of the following is the abbreviation for the element gold?
(a) G.
(b) $\mathrm{Fe}$.
(c) Au.
(d) Go.
(e) Ld.

Q8. What scientist is usually credited with inventing the PTE?
(a) Albert Einstein.
(b) Isaac Newton.
(c) Antoine Lavoisier.
(d) Dmitri Mendeleev.
(e) Alfred Nobel.

Q9. What is the abbreviation used in the PTE for hydrogen?
(a) Fe.
(b) $\mathrm{H}$.
(c) Hy.
(d) $\mathrm{Hd}$.
(e) Gn. 
Q10. What is the name of the family of elements that has a full outer shell of electrons?
(a) Alkali metals.
(b) Transition metals.
(c) Halogens.
(d) Actinoids.
(e) Noble gases.

\section{DEVELOPMENT OF AN EDUCATIONAL ACTIVITY}

Historia $F+Q$ developed an activity based on the PTE and its relationship with everyday life [33].

\section{Objectives}

1. Get acquainted with the PTE.

2. Acquire awareness that the elements of the PTE are found in everything around us and recognize their importance.

3. Learn the elements and their applications.

\section{Development of the Activity}

1. Get to know the students' previous ideas via the following questions.

Q1. What is the PTE?

Q2. Does anyone know any element of the PTE and any of its applications?

2. Project a video that shows elements of the PTE in people's daily lives.

3. Comment on the video asking what caught students' attention, and asking them to remember the elements and uses that were shown.

4. Detailed explanation of the basic characteristics of the PTE.

5. Group work activity. Give each group a few everyday objects (a light bulb, toothpaste, etc.), cards with three short sentences about the elements that these objects contain and other cards with their names, so that students can associate the three things. Write the symbol and $Z$ of the element, looking for it in a PTE shown in the lecture room. For reference they have illustrated PTEs.

6. Sharing of the elements with which students worked. Each student must talk about an element briefly.

\section{Evaluation Criteria}

1. Simple test with basic ideas about the work.

2. Assessment of group work.

3. Evaluation of the brief presentation on an element. 


\section{CHEMICAL ELEMENTS AND SOCIETY}

Some frequently asked questions that may disturb people were raised and answered [34].

Q1. What is a chemical element?

A1. A chemical element is called a substance that is composed of a single type of atom.

Q2. How is a chemical element formed?

A2. One of the most accepted theories suggests that the first chemical elements arose in the big bang; in the primitive universe, $\mathrm{H} / \mathrm{He}$ were formed, as the universe expanded the temperature dropped and over time the stars are the main natural factories of chemical elements, because of the nuclear fusions that take place in their cores.

Q3. Has one ever heard of supernovae?

A3. They occur when massive stars use up their fuels and form an Fe core, the gravitational force begins to dominate and the star begins to collapse to its centre.

Q4. What are the constituents of human bodies?

A4. O (65\%), C (18.5\%), H (9.5\%), N (3.3\%), Ca (1.5\%), P (1.0\%), K (0.4\%), S (0.3 \%), $\mathrm{Cl}(0.2 \%), \mathrm{Na}(0.2 \%), \mathrm{Mg}(0.1 \%), \mathrm{I}$ (traces), Fe (traces), Zn (traces), etc.

\section{PROJECT: THE ELEMENTS OF THE PERIODIC TABLE IN DAILYLIFE}

María Eugenia developed the Project: The Elements of the PTE in Daily Life [35].

4. Read the following text. As early as the $19^{\text {th }}$ century, chemists had a wealth of information about many elements (in 1869, 63 elements were known). Chemists needed to sort the information and tried to find criteria that applied to all of them; e.g., if one has a collection of soccer player figurines, you can sort them by team, country or position of the players on the field. Mendeleev (1869) was the first to achieve a successful arrangement, via the atomic masses of the elements and placing those that had something in common in the same column. By ordering them, he altered the mass order when necessary to locate them according to their properties and left gaps, which suggested the existence of unknown elements.

5. Watch selected videos. Currently, 118 elements are known, 92 of which are natural and the rest are man-made. In the current PTE, the elements are in increasing order of $Z$. Look for the image of a current PTE.

6. Building a Giant PTE. Materials. What is written in red serves as an idea and students should think in class how they are going to build a giant PTE. Coloured cards (brown, orange, white, light green, yellow, dark green, blue, purple, light blue), markers, glue, scissors, paper tape, images of materials that contain the chemical elements of the PTE. Procedure: Set up working groups; each group will have a certain number of chemical elements. For each chemical element, they must cut out two $20 \times 20 \mathrm{~cm}$ squares of cardboard. In the first square, which will go in front, they must write in black marker the symbol and the name of the element. Then they must paste images of materials from everyday life that contain that chemical element or paste 
those materials. In the other square, which will be behind, they must add information about the usefulness of that chemical element. Then students will assemble PTE together, sticking the coloured squares on a classroom wall.

7. Ideas in photos.

8. Hint: the PTE assembled last year.

9. Provide a link to upload the work.

10. Analyse the figures of this report, e.g., figures. 1-4.

11. Develop your own PTE project.

\section{DISCUSSION}

In contrast to physics, which is discussed via mathematics, chemistry developed a distinct language, which is organised and classified in terms of the PTE [36]. Chemistry uses unique visual representations of the structure of molecules in order to understand and explain the intricate structural differences and chemical properties of substances. The uniqueness of chemical practice and theorising means it deserves its own distinct philosophical investigation. Teaching physics and chemistry via their history: the PTE is the product of collective work, developed over a long period and in a number of places, by a large number of people, many of whom hardly feature in most common accounts [37]. This review confirms the creative role of teaching. It is collective creativity in which a large number of protagonists take part, from the teaching staff to the students, and the teams in charge of editorials and the management of educational policies. The PTE is present beyond the academic world. It is a source of visual forms that circulate creatively across linguistic boundaries, and can be handled in a number of social and cultural contexts. Since 1869, numerous ways of representing it existed as 2D/3D models. Controversies existed about the best way to visualise it, and the scope and limitations of each representation. Other forms of representing the elements emerged, e.g., abundance, that were inspired by the PTE to highlight problems that are not visible in the traditional forms. The PTE became an ingredient in the popular image of chemistry. With the resources, students can appreciate why they study chemical elements and what their applications are in their day to day lives. The learning of chemical compounds is no longer limited to memorizing and applying mnemonic rules. With the proposals, students can put into practice their ability to relate concepts and understand how the world works. Cooking and washing one's hands are familiar activities, which are questions of nutrition, hygiene and health, but people do them mechanically without stopping to think about the chemistry behind them [38]. Why? Why the prejudice about chemistry in people's daily lives? What can be done to bring people closer to chemistry? How many elements in the PTE could be depleted because of overexploitation? What is the PTE? What do the PTE groups have in common? Where does the PTE come from? Why does the PTE split? How is the PTE organised? We are familiar with the chemical symbols for hydrogen and oxygen, but can we do the same for lower-profile elements, e.g. Gd/Er? When was the PTE invented? Why is the symbol for potassium K? Why are the elements arranged in columns in the PTE? What is the pattern of behaviour? How is it correlated with the structure of the electrons outside the nucleus? How is the PTE structured [39]? What are the elements named? How is a chemical element classified? Classification varies depending on the author's focus. Does 
one know what elements were discovered by the Spaniards? Where are the elements in people's daily life? How much of them is left? Is it enough? What is the future of the PTE? ChemicalSafetyFacts. org is a search engine to find information on the chemicals that are essential for the products we use every day [40]. Everyday chemicals that are toxic and damage the environment were reviewed [41]. Chemical pollution is one of the most current environmental problems in the world. All households must develop a culture of chemical safety, in order to prevent risks to health and the environment by consuming responsibly, particularly products that contain corrosive, toxic or flammable substances that become hazardous waste. The walk on the exotic side of an element allows people to reflect on the fallacy of easily accepted postulates, e.g. assignment of positive values to the natural and negative to the chemical; such facts show the importance of research in basic sciences, beyond the direct utility of its discoveries [42]. To know an element, one must penetrate the oddities that it tends to hide. People see that the PTEs are not just a vital educational tool, they remain useful for researchers in their quest for essential materials [43]. People should not think of versions as replacements for earlier depictions. Having many different PTEs serves to deepen people's understanding of how elements behave. Current questions on the PTE are period 1, group 3 and further PTE extensions. One comprehensive database of PTEs and periodic system formulations exists [44-46]. The PTE is like turning a jungle into a garden (C. P. Snow). The PTE is the alphabet of the Universe. Was this a new area in science and public relations [47]?

\section{CONCLUSION}

From the discussion of the current results, the following conclusions can be drafted.

1. Reed's suggestions for the evaluation of screening constants of the $s, p$ and $d$-block elements were considered and Reed's rule for the evaluation of screening constants of $f$-block elements was extended. When electron-entire in the $5 f, 6 p$ and higher shells, the contribution of $4 \mathrm{f}$ as 1 was used. In the same shell, f electrons shield each other by a factor of 0.3228 .

2. The periodic arch represents the kind of mindset that is usually shared by engineers and artists. Electromagnetic signals are the root issue that needs to be revisited. Until the review is fully accomplished and widely disseminated, nanotechnology and other technologically important areas will be unnecessarily hampered.

3. The origins of the different chemical elements are as follows: the Big Bang, cosmic rays, small stars, large stars, supernovae and made in the laboratory.

4. Aromatic $\mathrm{CH}$ group $->\mathrm{N}$ atom exchange is a versatile design element for multiparameter optimisation that could lead to the identification of necessary $N$ atoms. Though generic effects and general trends exist, the specific impact is always context (ligand, target, antitargets, etc.)-dependent. However, 2-aza-analogues seem to have an increased probability of positive or neutral impact across multiple pharmacological parameters (not just potency).

5. How do atomic properties manifest in nuclear magnetic resonance spectra, using fluorine as an example? How to use selective ${ }^{19} \mathrm{~F},{ }^{13} \mathrm{C}$ and ${ }^{2} \mathrm{H}$-labelling to map structural features? 
6. The periodic table of the elements can serve as an introduction to the history of science, technology and medicine.

7. The achieved educational objectives are as follows: (a) begin to become familiar with the periodic table; (b) acquire awareness that the elements of the periodic table are found in everything that surrounds us and, therefore, recognize their importance; (c) learn elements and their applications.

\section{ACKNOWLEDGEMENT}

The author thanks Basilica Santa Maria de los Sagrados Corporales (Daroca, Zaragoza, Spain) and financial support from an internal aid from Universidad Católica de Valencia San Vicente Mártir.

\section{LITERATURE CITED}

[1] Bertomeu Sánchez JR, Muñoz Bello R. Darwinismo inorgánico, Pedagogía Química y popularización de la ciencia: La ley periódica en España a finales del siglo xIx. In: Díaz Rojo JA, editor. La circulación del saber científico entre los siglos XIX y Xx. Valencia: Instituto de Historia de la Medicina y de la Ciencia López Piñero; 2011. p. 25-61.

[2] Torrens F, Castellano G. Reflections on the nature of the periodic table of the elements: Implications in chemical education. In: Seijas JA, Vázquez Tato MP, Lin SK, editors. Synthetic organic chemistry. Basel (Switzerland): MDPI; 2015. Vol. 18, p. 1-15.

[3] Torrens F, Castellano G. Nanoscience: From a two-dimensional to a three-dimensional periodic table of the elements. In: Haghi AK, Thomas S, Palit S, Main P, editors. Methodologies and applications for analytical and physical chemistry. Waretown (NJ): Apple Academic-CRC; 2018. p. 3-26.

[4] Torrens F, Castellano G. The periodic table, quantum biting its tail, and sustainable chemistry. In: Torrens F, Haghi AK, Chakraborty T, editors. Chemical nanoscience and nanotechnology: New materials and modern techniques. Waretown (NJ): Apple Academic-CRC; 2020. p. 25-32.

[5] Torrens F, Castellano G. Periodic law. In: Putz MV, editor. New frontiers in nanochemistry: Concepts, theories, and trends. Waretown (NJ): Apple Academic-CRC; 2020. Vol. 1, p. 389-95.

[6] Torrens F, Castellano G. Periodic property. In: Putz MV, editor. New frontiers in nanochemistry: Concepts, theories, and trends. Waretown (NJ): Apple Academic-CRC; 2020. Vol. 1, p. 397-402.

[7] Torrens F, Castellano G. Periodic table. In: Putz MV, editor. New frontiers in nanochemistry: Concepts, theories, and trends. Waretown (NJ): Apple Academic-CRC; 2020. Vol. 1, p. 403-25.

[8] Torrens F, Castellano G. Periodic table of elements: Heavy, rare, critical, and superelements. In: Yaser AZ, Khullar P, Haghi AK, editors. Green materials and environmental chemistry: New production technologies, unique properties, and applications. Waretown (NJ): Apple AcademicCRC; 2021. p. 91-103.

[9] Torrens F, Castellano G. Periodic table, chemical bond nature, and nonclassical compounds. In: Yaser AZ, Khullar P, Haghi AK, editors. Green materials and environmental chemistry: New 
production technologies, unique properties, and applications. Waretown (NJ): Apple AcademicCRC; 2021. p. 105-13.

[10] Torrens F, Castellano G. Mesoporous, graphene composite, Li battery, topology, and periodicity. In: Kulkarni S, Rawat NK, Haghi AK, editors. Green chemistry and green engineering: Processing, technologies, properties, and applications. Waretown (NJ): Apple Academic-CRC; 2021. p. 149-62.

[11] Torrens F, Castellano G. Surfaces, quantum walks, knowledge, agrotoxins and periodic table. In: Haghi AK, editor. Renewable materials and green technology products: Environmental and safety aspects. Waretown (NJ): Apple Academic-CRC; in press.

[12] Chu H, Roh CJ, Island JO, Li C, Lee S, Chen J, Park JG, Young AF, Lee JS, Hsieh D. Linear magnetoelectric phase in ultrathin $\mathrm{MnPS}_{3}$ probed by optical second harmonic generation. Phys Rev Lett 2020;124:027601-1-6.

[13] Fleet N. Fabrication and characterisation of devices based on 2D niobium diselenide, Master Thesis, Universitat de València, València; 2020.

[14] Islam N. The orbital exponent efficacy to study the periodic parameters. In: Putz MV, editor. New frontiers in nanochemistry: Concepts, theories, and trends. Waretown (NJ): Apple Academic-CRC; 2020. Vol. 1, p. 377-80.

[15] Whitney C. Periodic arch. In: Putz MV, editor. New frontiers in nanochemistry: Concepts, theories, and trends. Waretown (NJ): Apple Academic-CRC; 2020. Vol. 1, p. 381-7.

[16] Cortina D, personal communication.

[17] Chiocchetti GM, Latorre T, Clemente MJ, Jadán-Piedra C, Devesa V, Vélez D. Toxic trace elements in dried mushrooms: Effects of cooking and gastrointestinal digestion on food safety. Food Chem 2020;306:125478-1-7.

[18] Guillem-Llobat X, Nieto-Galan A, editors. Tóxicos invisibles: La construcción de la ignorancia ambiental, Antrazyt No. 504. Barcelona: Icaria, 2020.

[19] González Gaya B. La contaminació invisible: Contaminants marins emergents. Mètode 2020;4(107):61-9.

[20] Valero Molina R. El sistema periódico y su relación con la vida cotidiana. Parte I. An Quím 2013;109:301-7.

[21]@Alvy. La tabla de los elementos, con dibujos sobre el uso cotidiano de cada uno de ellos. Microsiervos 2026;2016(Nov. 8): 1-1.

[22] AG J. La tabla periódica que muestra la utilidad real de cada elemento químico. El Español 2016;2016(Nov. 23):1-1.

[23] Semana Sostenible. Los elementos de la tabla periódica en artículos de la vida cotidiana. Semana Sostenible 2017;2017(Jan. 27):1-1.

[24] Asimov I. Building blocks of the Universe. New York (NY): TBS; 1958.

[25] Van den Berg E. La mejor tabla periódica ilustrada para estudiar los elementos y enterarse. El País 2017;2017(Aug. 2):1-1.

[26] Biogeociencia. Tabla periódica de los elementos en objetos cotidianos. Biogeociencia 2018;2028(Sep. 26):1-1.

[27] TICbeat. Esta tabla periódica te enseña dónde está cada elemento químico en tu vida cotidiana. TICbeat 2019;2019(Jul. 3):1-1. 
[28] Espinosa A. Desde tu celular hasta un submarino, ¿para qué usamos cada elemento químico en la vida diaria? Animal MX 2019;2019(Oct. 18):1-1.

[29] Lomelí Pacheco MA. La tabla periódica química en nuestra vida diaria. Universitarios Potosinos 2020;243:36-7.

[30] Del Hoyo Campillo MD. Una vida con la tabla periódica. Gobierno de Canarias 2020;2020(Apr. 20):1-1.

[31] Educación 3.0. Objetos cotidianos para explicar los elementos químicos. Educación 3.0 2020;2020(Dec. 21):1-1.

[32] Ducksters. Periodic table. Ducksters 2021;2021(Jan. 8):1-1.

[33] Historia $\mathrm{F}+\mathrm{Q}$. El sistema periódico y su relación con la vida cotidiana. Historia $\mathrm{F}+\mathrm{Q}$ 2019;2019(Apr. 23):1-1.

[34] Cruz Toalá OA. Los elementos químicos y la sociedad. Chiapas Paralelo 2019;2019(Sep. 17):1-1.

[35] MA. Actividad 5: Proyecto: Los elementos de la Tabla Periódica en la vida cotidiana. ORT Argentina 2020;2020(Oct. 30):1-1.

[36] Seifert V. The philosophy of chemistry... and what it can tell us about life, the universe and everything. The Conversation 2016;2016(May 10):1-1.

[37] Bertomeu Sánchez JR. Clasificar y disciplinar: El orden de los elementos. Investigación y Ciencia 2020;2020(Sep. 16):1-1.

[38] García C. La Química de todos los días. Noticias ONU 2019;2019(Sep. 4):1-1.

[39] Química y Sociedad. El ABC de la Tabla Periódica. Madrid: Química y Sociedad; 2019.

[40] ChemicalSafetyFacts.org. Chem in context topics: Productos químicos de uso cotidiano. ChemicalSafetyFacts.org 2021;2021(Jan. 5):1-1.

[41] Quintanar Ordóñez S. Sustancias químicas de uso cotidiano las cuales son tóxicas y dañan el medio ambiente. Con-Ciencia 2021;2021(Jan. 5):1-1.

[42] Martínez Camarena A, personal communication.

[43] Norman N. Periodic table: Scientists propose new way of ordering the elements. The Conversation 2020;2020(Nov. 26):1-1.

[44] Leach MR. The chemogenesis web book: The Internet database of periodic tables. Manchester (UK): Mark R. Leach; 2021.

[45] Anastas PT, Zimmerman JB, The periodic table of the elements of green and sustainable chemistry. Green Chem 2019;21:6545-66.

[46] Walter P. Elements of green chemistry. Chem World 2019;2019(Aug. 7):1-1.

[47] Bensaude-Vincent B. Book of Abstracts, $6^{\text {th }}$ World Forum on Science and Democracy; 2021 Jan 25-30; Internet. Porto Alegre (Brazil): World Social Forum; 2021. RT-8. 